\title{
The Implementation of Video in Teaching Writing Recount Text at Al-Fattah Buduran Sidoarjo
}

\author{
Mia Fauzia Farida \\ Dian Novita \\ English Education Department, Faculty of Teacher Training and Education, \\ Universitas Muhammadiyah Sidoarjo \\ Jl. Majapahit, 666B, Sidoarjo
}

\author{
*E-mail Corresponding Author: \\ miafauziafarida@umsida.ac.id
}

\begin{abstract}
The objectives of this research are to identify how the implementation of video in teaching writing recount text and to know the students' response about the implementation of video in teaching writing recount text. The subject were tenth grade of X-IPA of SMA Al-Fattah, Buduran, Sidoarjo in the academic 2017/2018. This research used qualitative descriptive were obtained by observing the teaching and learning activity during the implementation of video in teaching writing recount text in the class. Besides, the researcher gave questionnaire, did interview and took pictures for documentation. In this study, the teacher taught about historical event in writing recount text. There are various kind of the student's responses, but most of them like the implementation of video in teaching writing recount text. From the result of this research, students feel more enjoy with the application of video media in learning than not using any media.
\end{abstract}

Keywords-Recount Text; Writing; Video

\section{INTRODUCTION}

Language is the most important thing in human life. We are as human being need to communicate and interact wih other people. Humans live together and of course need each other in society, so it is impossible if humans live alone. According to [1] "language as crucial tool in the learning process that has been long recognized by many people". That is why humans need help from others, need a tool to convey or deliver much information, to express their feelings and ideas. writing is the most difficult skill for second learners to master, because there are several difficulties that students face, they are in generating and organizing ideas, and also in translating these ideas into readable text in paraghraph. Writing extremely important because to inform the information, explain and describe something, to argue some problems, persuade and instruct, entertain, to analyze, review and comment everything in written form. According to [2] writing can be used to express the student's idea as well as feelings and to communicate with others, therefore writing should be mastered by the learners.

English is an international language that used in many counries. According to Harmer (2001:1) English as main language of international communication that is used by many people. english is the easiest way to communicate with people around the world and we can use english with them to share about everything like many aspects in human life such as socual, technologies, and politics. In Indonesia, english as a foreign language that have four skills in learning, they are speaking, reading listening, and writing. Actually, English learners are expected to master all of the skills, but the fact is different. Some of English learners are good in speaking skill but not in writing skill and otherwise. It means that not all of English learners master all the skills of English because they have different ability in learning language.

Acording to Bryne in Ghufron (2012:4) writing involves some kinds of message that we think and we transfer our thoughts into language in written form. Therefore, writing process needs much time to finish because there are some steps. Writing is one of difficult skills because the students get low vocabulary mastery. According to Richards and Renandya (2002:303) writing is the most difficult skill for second learners to master, because there are several difficulties that students face, they are in generating and organizing ideas, and also in translating these ideas into readable text in paraghraph. Writing extremely important because to inform the information, explain and describe something, to argue some problems, persuade and instruct, entertain, to analyze, review and comment everything in written form. According to Cahyono (2009:27) writing can be used to express the student's idea as well as feelings and to communicate with others, therefore writing should be mastered by the learners.

The researcher found that there are some problems occured in writing process, especially for students. Based on the preliminary on November, 20th 2017 the researcher did interview with the teacher of tenth grade at SMP AlFattah Buduran Sidoarjo. The teacher said that students sometimes feel bored when the teacher gives them materials about English, and they get difficulties in writing. [3] states the teacher should use variety of teaching aids to explain the lesson, engage the students in a topic, or as the basis of a whole activity. Therefore, the teacher should be 
creative in teaching especially writing. Teacher can handle the situation in the class, the teacher connects a topics with the real situation and the learners feel enjoy in learning writing.

Based on the preliminary research the teacher will use video from movie to teaching writing recount text. The teacher said the reason she using video in the classroom, video is really good media for the teacher because it has power to make students interest in writing. For example, the students get an idea after watching the video and they also can develop their idea based on the video. Beside that, video is a tool in teaching learning English. It means that the teacher can teach the students easily and the students will get spirit to start writing recount text. [4] there are difficulties that the students face in writing recount text. First, the learners get difficulty to find a good idea and tell their past experiences by using past tense. Second, the learners get difficulty to write the paraghraph coherently by using suitable conjunctions. Therefore, recount text is not easy for tenth garde in senior highschool students because still have difficulties in learning. Another statement from [5] the students get dificulty in learning past tense and it happened when the teacher failed to develop the rule to make an acceptable utterences, the students did not understand the structure of past tense, the students always regularized the irreguler verb.

According to [6], video as media which use in teaching and learning process has many benefits to the students. Video substitue for the natural surroundings and can show objects that normally can not be seen by students such as food digestion and breathing process. Therefore, video can describes a process appropiately and can seen repeatedly. Video also encourages and enchance student's motivation to keep in view. Based on the positive feature of video in teaching writing recount text and the significance of mastering writing skill. Usually students are more spirit in learning by using media especially video, because video make them enthusiast and enjoy in learning and can momentarily eliminate the student's bored during learning.

\section{METHODOLOGY}

Type of the research used descriptive qualitative. The goal of qualitative descriptive studies is a comprehensive summarization, in everyday terms, of specific events experience by individuals or group. Descriptive qualitative studies researcher tend to not penetrate their data in any interpretive. These studies present comprehensive summaries of phenomenon of events. Based on the research questions and the objectives of the study in the previous chapter, the researcher uses a descriptive explanation to gather information that related to the implementation of video in teaching writing recount text. The result of this research would be in the form of description and explanation of some phenomena which happened during the observation. The subject of this study is 10th grade students of SMP Al-Fattah Buduran Sidoarjo and the English teacher. There 2 classes of the tenth grade, but the researcher chooses 10 IPA as the subject of the study because the students in that class are more active and enthusiasm when they learn English.

\section{Observation}

Data confirmation was done by observing the class practice. This observation was done through nonparticipant observation to know the teacher used video to teach writing recount to the tenth grader and also to know how the students responses toward the video which is used by the teacher both their motivation and their interest. The obsevation was done in two meetings.

In the first meeting the teacher will explain first about definition of recount text, generic structure, and language feature about recount text. The teacher also give the student's exercise about recount text in order to practice before they do exercise using video as media. In second meeting the teacher will review the material about recount text, and then use the video to teach the students in teaching writing recount text.

\section{Questionnaire}

The researcher uses the questionnaire to answer the research problem about the student's responses during the implementing video in teaching writing procedure text. The questionnaire consists about the implementation of video in teaching writing recount text. The researcher would know about what students feels after the implementation by using questionnaire.

\section{Interview}

Wilkinson and Birmingham (2003:45) divided interview into three types. They are : structured interview, semistructure interview and unstructured interview. Thus, the researcher used unstructured interview in this research. The unstructured interview was a very flexible approach. Areas of interest was establish by the researcher but the discussion of issues was guided by the interviewed.

In this research, the researcher interview the students's opinion about the implementation of using video in teaching writing recount text.

\section{Documentation}

The documentation is a record of events that had passed. According to Sugiyono (2015:329) the documents could be in the form of images, texts or monumental works of someone. The documentation uses for collecting data about student's behavior and activities in the class, like how students behavior when the teacher explains the 
material, how to guide the student's activity in the class, how to know the student's understanding and student's score, etc.

\section{FINDINGS AND DISCUSSION}

\section{Observation}

Data confirmation was done by observing the class practice. This observation was done through nonparticipant observation to know the teacher used video to teach writing recount to the tenth grader and also to know how the students responses toward the video which is used by the teacher both their motivation and their interest. The obsevation was done in two meetings.

In the first meeting, the researcher did observation in the class. The researcher matching the activities taught by the teacher to students regarding recount text material with lesson plans. In the second meeting almost same with the first meeting, the researcher did obesrvation in the class and matching the activities taught by the teacher to the students regarding how the teacher implement the video to teach the students in recount text materials with lesson plans.

\section{Questionnaire}

The researcher shared the questionnaire in the second meeting after the teacher implemented the video in teaching writing recount text to answer the research problem about the student's responses during the implementing video in teaching and learning writing recount text. The researcher would know about what student's feels and responses after the implementation of video by using questionnaire.

\section{Interview}

The researcher used unstructured interview in this research. The unstructured interview was a very Flexible approach. Areas of interest was establish by the researcher but the discussion of issues was guided by the interviewed.

In this research, the researcher interview the students's opinion after the teacher implemented the video in Teaching and learning writing recount text in the second meeting. The researcher did interview to support the data of questionnaire.

\section{Documentation}

The documentation is a record of events that had passed. The documents could be in the form of images, texts or monumental works of someone. The documentation uses for collecting data about student's behavior and activities in the class, like how students behavior when the teacher explains the material, how to guide the student's activity in the class, how to know the student's understanding and student's score, etc.

The researcher did documentation in the first meeting and second meeting. The researcher took videos when the teacher was teaching the students and student's activities in the class. Besides that, the researcher also took photos when teaching and learning process and also the researcher took recordings when interviewing students after the teacher implemented the video in teaching writing recount text.

\section{CONCLUSION}

Based on the result of the observation all of the activity in the first meeting and second meeting were doing well. Eventough actually the teacher did the activity was unappropiated with the lesson plan, but the reseracher thought it still going well. The result showed that that used of video is able to improve the students writing skill to explore their ideas, to use proper word in their sentences. Using video in teaching recount text, the students can clearly listened what the characters said in the video. The students responses also shows that they were active in writing activity and they agreed that the use of video in teaching recount text it is helpful for them to develop and organize their ideas systematically and to make the be motivated to write a text.

In addition, they can see the storyline and automatically saved in their memory as opposed they should create Recount text just by reading the story in the book. They are confident when they write a text, especially in recount text. Using video in teaching writing recount text also can improve the student's competence in writing. Furthermore, teaching writing recount text with video is not the only way that can improve students' writing abilty. It should be supported by the teacher and students' condition and situation in learning.

\section{ACKNOWLEDGEMENT}

This research can be accomplished with any guidance from Mrs. Yuli Astutik, M.Pd. as the Head of English Education Department and advisor of this research, and all English lecturers in UMSIDA who have been taught sincerely. 


\section{REFERENCES}

1. Arsyad. Azhar, Media Pembelajaran. Jakarta: PT Raja Grafindo Persada. 2011.

2. Brown. H. Douglas, Language assessment: Principles and classroom practices. 2005, 5.

3. Cahyono. B, Buku Terlengkap Sukses Bertanam Buah Naga. Jakarta: Pustaka Mina. 2009, 27.

4. Fadzilyna, Errors in Using Past Tense Made by Eighth Graders of MTsn Model Trenggalek. Published thesis. Malang: State University of Malang. 2013.

5. Fani. Landriani write a research entitle "The Use of Video in Teaching Writing Procedure Text for the Seventh

6. Grade". 2016

7. Harmer. Jeremy, The Practice of English Language Teaching, 3rd Ed, New York: Pearson Education Limited.

8. 2011.

9. Harmer, J. How to teach Writing. Malaysia :Pearson Education Limited. 2011.

10. Istibsyaroh, Istibyaroh. Grammatical Errors on Students' Writing of Recount Text. 2014.

11. Nila. Rulia and Muhd. Al-Hafizh, "Teaching Writing Recount Text by Using Mr.Bean Video to Junior High

12. School Studets". 2014

13. Richards, J .C. and Renandya, W .A, Methodology in Language Teaching (An Anthalogy of Current Practice). United States of America: Cambridge University Press. 2002. 